\title{
EDUCATION AND REVOLUTIONS.
}

Why do revolutionary uprisings take violent or nonviolent forms?

\author{
Vadim Ustyuzhanin \\ HSE University, Moscow \\ ORCID 0000-0003-3800-1108
}

\author{
Andrey Korotayev \\ HSE University, Moscow \\ Institute for African Studies, Russian Academy of Sciences, Moscow \\ ORCID 0000-0003-3014-2037
}

\begin{abstract}
Is there a relationship between education and the type of revolutionary action - violent or nonviolent? Past studies found a positive relationship between the education and nonviolence, but the influence that education produces on the form that revolution takes has not yet been explored. This paper examines it at a cross-national level with an analysis of 470 NAVCO 'maximalist campaigns' and 265 revolutionary events recorded between 1950 and 2020. Tests using logistic regression and our own index support the hypothesis that mean years of schooling is a usable, strong and consistently significant predictor of the unarmed form of revolutionary action. Moreover, it is also found that education has the highest pacifying effect in the early stages of modernization, but then this effect gradually decreases and in developed countries education has a less strong pacifying effect.
\end{abstract}

KEYWORDS: education, revolutions, nonviolent revolution, violent revolution, destabilization, protest campaigns 


\section{Introduction}

In 2001 Jack Goldstone made the following observation:

'Until very recently, revolutions have invariably failed to produce democracy. The need to consolidate a new regime in the face of struggles with domestic and foreign foes has instead produced authoritarian regimes, often in the guise of populist dictatorships such as those of Napoleon, Castro, and Mao, or of one-party states such as the PRI state in Mexico or the Communist Party-led states of the Soviet Union and Eastern Europe. Indeed, the struggle required to take and hold power in revolutions generally leaves its mark in the militarized and coercive character of new revolutionary regimes. It is therefore striking that in several recent revolutions in the Philippines in 1986, in South Africa in 1990, in Eastern European nations in 1989-1991 the sudden collapse of the old regime has led directly to new democracies, often against strong expectations of reversion to dictatorship' (Goldstone 2001 168).

Since that time the number of such revolutions has increased even more, and in the $2000 \mathrm{~s}$ and 2010s one could observe the emergence of a considerable number of studies dedicated to the answer to the question why some revolutions lead to democratic rather than authoritarian outcomes (Ackerman and Karatnycky 2005; Stephan and Chenoweth 2008; Johnstad 2010; Stradiotto and Guo 2010; Chenoweth and Stephan 2011; Celestino and Gleditsch 2013; Bayer, Bethke and Lambach 2016; Butcher and Svensson 2016; Kim and Kroeger 2019; Rasler, Thompson and Bou Nassif 2021).

Note that most of these authors prefer to denote revolutions as 'maximalist campaigns'. Following Ackerman and Kruegler (1994, 10-11), Chenoweth and Stephan $(2011,14)$ define 'campaign' as “a series of observable, continual, purposive mass tactics in pursuit of a political objective." What is more, the abovementioned studies consider campaigns "with goals that are perceived as maximalist (fundamentally altering the political order); ...we deliberately choose campaigns with goals commonly perceived to be maximalist in nature: regime change, antioccupation, and secession' (Chenoweth and Stephan 2011, 68). Thus, the abovementioned 
works study "series of observable, continual, purposive mass tactics in pursuit of fundamentally altering the political order: regime change, antioccupation, and secession". We ourselves rely on such definitions of revolution as "a revolution is a collective mobilization that attempts to quickly and forcibly overthrow an existing regime in order to transform political, economic, and symbolic relations" (Lawson 2019, 5); 'anti-government (very often illegal) mass actions (mass mobilization) with the following aims: (1) to overthrow or replace the existing government within a certain period of time; (2) to seize power or to provide conditions for coming to power; (3) to make significant changes in the regime, social or political institutions' (Goldstone, Grinin and Korotayev 2021b), or "an effort to transform the political institutions and the justifications for political authority in a society, accompanied by formal or informal mass mobilization and noninstitutionalized actions that under-mine existing authorities" (Goldstone 2001, 142). Thus, we find that "maximalist campaigns" are just nothing else but revolutions (including national liberation ones); hence, the abovementioned works actually study revolutions (rather oddly denoted as “campaigns"). This point is further supported by the fact that Chenoweth's database of Nonviolent and Violent Campaigns and Outcomes (NAVCO) designates as campaignsall the indisputable revolutions since 1900 - including Russian revolutions of 1905-1907 and 1917, Constitutional Revolution in Iran, Xinhai Revolution in China, Mexican Revolution of 1910-1917 and so on (Chenoweth and Shay 2020a). Thus, the results of the abovementioned studies on the outcomes of "maximalist campaigns" turn out to be perfectly relevant for our understanding of the out-comes of revolutions.

It is highly remarkable that the main finding of the abovementioned studies (supported by a number of rather rigorous tests on the basis of a very wide range of worldwide empirical data) is that violent revolutions ('campaigns') are very unlikely to lead to the formation of stable democratic regimes, whereas this is much more probable as a result of nonviolent revolutions (Ackerman and Karatnycky 2005; Stephan and Chenoweth 2008; Chenoweth and Stephan 2011; Butcher and Svensson 2016; Kim and Kroeger 2019; Rasler, Thompson and Bou Nassif 2021). 
Against this background, it is a bit surprising that there seems to be only few systematic quantitative global cross-national studies of factors of violent vs. non-violent revolutions (Butcher and Svensson 2016; Dahlum 2019). And some of the findings of these papers appear quite relevant. Of special importance is that Butcher and Svensson $(2016,324-325)$ show that the likelihood of onset of nonviolent revolutions (but not violent ones) increases significantly with the increase of the level of education (operationalized through average years of schooling) of the population of a respective country. Of course, in conjunction with the abovementioned finding that the nonviolent revolutions are more likely to lead to a stable democracy than the violent ones are, this suggests that in a country with a very highly educated population a revolution is quite likely to lead to the establishment of a stable democracy; but, on the other hand, this imply that in a country with a very poorly educated population a revolution is much more likely to be violent and, thus, is very unlikely to produce a democratic outcome.

Similar conclusions were arrived by Dahlum (2019): campaigns with a large number of students and graduated participants are more likely to be nonviolent and more likely to reach success. Note that the main independent variable used by Dahlum, Combined Education Index, takes into account the education level of the campaign participants only. ${ }^{1}$ Essentially, Dahlum created a fundamental base for our research and provided robust results that education promotes nonviolent strategies within protests campaigns. However, these findings must be expanded and tested on a more focused sample, including exclusively revolutionary events, not just the large protest campaigns presented by Dahlum². Moreover, her combined education index, the main explanatory variable, was created by herself and cannot be updated constantly. In other words, if one wants to replicates revolutionary events by this index, one will be oppressed to find an enormous amount of information for incomplete data for years since 2006. Moreover, the main

\footnotetext{
${ }^{1}$ What is more, Dahlum only takes into account the tertiary education, for her there is now difference between the situation when the majority of rebels are illiterate or have complete secondary education (if both rebellions have equal proportion of students and graduates). We do not find such an assumption really convincing.

${ }^{2}$ The campaign data in her research were taken from the NAVCO database, which will be discussed below.
} 
problem with it is that "the majority of criteria are based on the sources' descriptions of who the movement consisted of" (Dahlum 2019, 288). Thus, it can only be collected just post facto and has no predictive power for an understandable reason. Of course, this index may have more explanatory power, but it is not the ultimate cause, only the immediate cause determining violent $v s$. non-violent form of the revolutionary action. Thus, the novelty of this paper is not only the analysis of the education influence on the form of revolutionary events but also the identification of a viable independent variable that can not only describe the form of revolutions post factum but also can predict the form of forthcoming revolutions.

Turning to the main point, reviewed studies see a clear connection between the level of education and the choice of tactics for nonviolent resistance by the protesters, but this hypothesis has not been tested. Previous researchers found a consistent relationship between the likelihood of a peaceful protest and education (Machado, Scartascini and Tommasi 2011; Brancati 2014; Butcher and Svensson 2016; Kostelka and Rovny 2019; Korotayev et al. 2020; Sawyer and Korotayev 2021), but they did not investigate how education influences the choice of tactics of the protesters.

Thus, there are several reasons for educated people to choose the tactics of non-violence. They can be summarized as follows: (1) education changes ideological preferences in favor of democracy and commitment to civil liberties, fostering a culture of peaceful discussion and tolerance (Lipset 1960; Galston 2001; Dee 2004; Inglehart, Puranen and Welzel 2015; Dahlum 2019); (2) as a result of getting education, individuals increase the level of human capital, which leads to a rise in the relative costs of participating in violent revolutions/campaigns that require taking more risks and abandoning the usual life (Hall, Rodeghier and Useem 1986; Thyne 2006; Barakat and Urdal 2009; Dahlum and Wig 2019; Østby, Urdal and Dupuy 2019; Dahl et al. 2020); (3) education lowers the cost of participating in a peaceful revolution/protest by facilitating cooperation and understanding political processes, which makes it possible to achieve success through nonviolent revolutions/campaigns recognized as more successful and less costly (Galston 
2001; Dee 2004; Glaeser, Ponzetto and Shleifer 2007; Stephan and Chenoweth 2008; Rabou 2016; Dahlum 2019; Grinin and Korotayev 2021); (4) proliferation of formal education leads to the increase of share of highly educated people (including students) in the revolutionary protests; with the development of women's education, the number of female protesters is growing, and women are much less prone to violence and even more armed violence (Grinin et al. 2017; Dahlum 2019; Korotayev and Zinkina 2021).

Considering the first reason, it is worth noting that Lipset $(1960 ; 1968)$ argued that education expands access to information and promotes democratic-liberal values (such as freedom of speech or recognition and respect for the rights of another person) with an emphasis on the development of so-called civic knowledge fostering tolerance in individuals and allowing them to see the world from the perspective of other people who are not like themselves (Dee 2004; Inglehart, Puranen and Welzel 2015; Dahlum 2019). In other words, education fosters interpersonal interaction and empathy, generating aversion to violence (Pinker 2011), while its absence, on the contrary, makes people more militarized and inclined to accept the possibility of resolving disputes through violence due to a simplistic view of politics and an inability to understand the meaning behind tolerance and compromise with people you disagree with (Shayo 2007). Thus, less educated individuals are more prone to violence, while educated people are sickened by their preference effect (Dahlum 2019).

It is also important to consider that education reduces the propensity to violence because of the high costs associated with the opportunity cost of their labor and investment in themselves. It assumes that people with low opportunity costs are more likely to engage in collective violence (Hall, Rodeghier and Useem 1986; Dahlum and Wig 2019). Thus, education provides people with qualifications that increase the value of their labor in the market and improve their well-being, which makes violent protest tactics incredibly expensive (Thyne 2006; Barakat and Urdal 2009; Østby, Urdal and Dupuy 2019). Moreover, an armed conflict presupposes a rejection of the usual way of life, that is, of the familiar earnings, in favor of long and extremely dangerous actions 
associated with the risk of depriving the accumulated investment in human capital - death (Hegghammer 2013). At the same time, peaceful protests allow one to quickly switch between ordinary life and protest, which naturally reduces the costs of missed opportunities (Dahl et al. 2020). In other words, the larger number of prospects for improving welfare that education offers will be lost, making armed tactics unprofitable (Inglehart, Puranen and Welzel 2015). Consequently, recruiting rebels becomes prohibitively expensive with respect to educated people, which makes it less likely that the opposition will choose this path of revolutionary protest (Collier 2004; Barakat and Urdal 2009).

Moreover, education not only increases the costs of participating in violent conflict but also lowers the costs of participating in nonviolent conflict. Thus, educated people have the necessary potential for peaceful protest and, therefore, are more likely to choose nonviolent tactics (Dahlum 2019), because education provides them with the necessary resources to organize and succeed in peaceful protests, which are considered more effective but also more difficult from an organizational point of view (Stephan and Chenoweth 2008; Dahlum 2019). For example, educated people are more likely to use the media (Dee 2004), which increases the speed of news dissemination necessary for mass mobilization and success. This factor has become especially important only recently due to technological progress and the emergence of various social networks that stimulate political expression and participation from below, giving each tribune and the opportunity to participate in the political process independently (Akaev et al. 2017; Enikolopov, Makarin and Petrova 2020). In addition, education increases communication skills and teamwork (Green, Ashton and Felstead 2001), as well as facilitates understanding of policy and reduces the cognitive costs of decision-making bypassing various bureaucratic and technological barriers to civic participation (Dee 2004). In other words, more knowledge helps to better recognize public policy and more effectively promote one's point of view in the political sphere (Galston 2001), which creates the necessary individual resource base for participation in peaceful protests (Stephan and Chenoweth 2008; Chenoweth and Ulfelder 2017; Dahlum 2019). 
Consequently, the gains from choosing this particular tactic increase. Thus, education not only provides people with political knowledge but also facilitates cooperation between them, which expands the possibilities for choosing tactics of protest. Simply put, education lowers the material and cognitive costs of political participation (Rabou 2016), making the possible benefits of participation greater (Glaeser, Ponzetto and Shleifer 2007), which Dahlum (2019), for example, calls 'capacity-enhancing effect'.

Thus, education has a pacifistic effect, because it increases the level of human capital, reduces the relative costs of organizing protests leading to an increase in the likelihood of peaceful revolutionary protests (Brancati 2014; Sawyer and Korotayev 2021), and makes violence unacceptable on the personal level, instilling in people a tendency to tolerance (Jenkins and Wallace 1996). In general, it is confirmed by empirical studies: researchers find that the average number of years of schooling is positively and significantly associated with the level of peaceful protests (Brancati 2014; Butcher and Svensson 2016; Korotayev, Bilyuga, and Shishkina 2018; Korotayev et al. 2020; Kostelka and Rovny 2019; Machado, Scartascini and Tommasi 2011; Sawyer and Korotayev 2021). But at the same time, it is negatively associated with the likelihood of a civil war, which appears as an extreme form of violent revolutionary conflict (Collier 2004; Barakat and Urdal 2009).

Finally, our main hypothesis can be formulated as follows:

H: revolutionary uprisings in countries with significantly higher values of mean years of schooling $^{3}$ are significantly more likely to take nonviolent ${ }^{4}$ rather than violent form than in countries with significantly lower values of this variable.

\footnotetext{
${ }^{3}$ The discussion of this indicator can be found in the next section.

${ }^{4}$ Or, to be more exact, "unarmed" form. In fact, Kadivar and Ketchley (2018) quite convincingly show that the participants in the majority of the so-called "nonviolent maximalist campaigns" resorted to violence on a fairly serious scale (here one can recall, for example, the Egyptian revolution of 2011 or the Ukrainian revolution ["Euromaidan"] of 2013-2014, which Chenoweth and Shay (2020a) quite confidently qualify as "nonviolent maximalist campaigns" ), in connection with which they, with good reason, believe that it is wrong to call such revolutionary events "nonviolent", suggesting rather to designate them as "unarmed".
} 


\section{Materials and methods}

\section{Methodology and empirical strategy}

In order to test our hypotheses, we introduce our independent variable for the mean years of schooling in the model along with other control variables related to the modernization process (as well as some other variables) that tend to predict the type of revolutionary uprising - violent or nonviolent. So as to provide evidence that level of education is responsible for it, we also add controls for the area, population density, youth budge, GDP per capita, urbanization, population size, and index of electoral democracy. For our dependent variables, we include the binary variable 'Nonviolent versus Violent'. Each of these variables and their predicted effects are further described in the following section.

It is also important to emphasize that we have to use the logistic model, as we employ dichotomous dependent variables. This particular method is supposed to describe a probability, which is always some number between 0 and 1 . Thus, for the logistic model, we can never get a risk estimate either above 1 or below 0 (Kleinbaum et al. 2002).

\section{Dependent variable}

We rely on data provided by The Nonviolent and Violent Conflict Outcomes (NAVCO) 1.3, which identifies 622 maximalist/revolutionary campaigns that occurred between 1900 to 2019 (Chenoweth and Shay 2020b, 6). These data combine numerous instances of violent and nonviolent maximalist/revolutionary campaigns with the goals of expelling foreign occupation, regime change or separatism, and in some cases other major types of social change (such as campaigns against apartheid). In addition, Chenoweth and Shay identify whether the campaign was successful, achieved its goals or failed, and some other characteristics. However, we are interested in another variable provided by Chenoweth and Shay - whether the campaign was 
violent/unarmed or not. ${ }^{5}$ It is this variable that will be the dependent variable in this paper. Thus, it is a binary variable, where ' 1 ' is a nonviolent/unarmed revolutionary uprising/campaign and ' 0 ' is a violent one.

Note that NAVCO also contains a considerable number of so-called quasi revolutionary episodes, which Goldstone, Grinin, and Korotayev (following Beissinger 2017, 2021) define as episodes with "mass mobilization, but there are no demands to overthrow the government, or sufficient efforts are not made to overthrow the government and seizing power (there is no evidence that there have been serious attempts to overthrow the government and seize power)" $(2021,7)$. As an example, we can recall such cases recorded in the NAVCO as "Denim revolution" (or the so-called "Jeans Revolution") in Belarus (2006) or similar "Dissenter's March" in Russia (2007-2008) which cannot be called revolutions/failed revolutions, or even revolutionary episodes. "Denim revolution" (post-election anti-Lukashenko protests) took place just a few days in March 2006, most of which the number of participants was only a few hundred (see, e.g., Korosteleva 2009), and no serious attempts to take power were undertaken. ${ }^{6}$ Similarly, during the “Dissenters' Marches" in Russia (2007-2008), or "Kefaya” movement events in Egypt (20002005) no serious attempts to take power were undertaken (Clarke 2011; Gabowitsch 2016), and, together with Mark R. Beissinger $(2017 ; 2021)$, we prefer to denote such events as "quasi revolutionary".

Thus, in order to check if the results obtained for NAVCO turn out to be valid for the revolutionary events proper, we implement the dataset for 1950-2021 that describes only

\footnotetext{
${ }^{5}$ Chenoweth and Shay themselves emphasize that "campaigns are primarily nonviolent when the vast majority of participants are unarmed, and when they use mostly nonviolent practices to confound, impede, and challenge the regime and its supporters. Campaigns are primarily violent when most participants use force, especially armed force, to target regimes and their supporters" (Chenoweth and Shay 2020b ,6).

${ }^{6}$ This stands in a sharp contrast with the Belarusian Revolution of 2020-2021, when the protests continued for a few months, involved hundreds thousand participants, with the opposition forming a specific body claiming its rights to take power in the country and undertaking specific steps to achieve this goal (e.g., Moshes and Nizhnikau 2021). We are ready to denote such events as a (failed/unsuccessful [at least, by the moment]) revolution/revolutionary episode, but we are not ready to denote as such the post-election anti-Lukashenko protests of March 2006. The point that some members of the Belarusian opposition opted to call the March 2006 events "Denim Revolution" or "Jeans Revolution" reflects first of all the unrealized hopes of some of them that those events would develop in a true revolution; the same is relevant, e.g., for the so-called "Snow Revolution" that took place in Russia in winter 2011/2012 (see, e.g., Gabowitsch 2016).
} 
revolutionary events (revolutions, failed revolutions/revolutionary episodes, revolutionary guerrilla warfare, analogues of revolutions and failed revolutions) without any quazi-revolutionary episodes. It contains events from the database of the $21^{\text {st }}$ century revolutions (reproduced in the online appendix) augmented for the 1950-1999 period with the events from the dataset of the $20^{\text {th }}$ century revolutions developed by L. Grinin and A. Grinin (2021) as well as those revolutionary events of the $20^{\text {th }}$ century that are present simultaneously both in Franziska Keller's dataset of revolutions (Keller 2012) and in NAVCO (Chenoweth and Shay 2020a). In this way, we have a comprehensive list of revolutionary events between 1950 and 2021. This dataset will allow us to test whether conclusions drawn from the NAVCO work for revolutionary events proper (excluding quasi revolutionary episodes). Moreover, this dataset is necessary for testing the ability of Dahlum's index to explain the violent / nonviolent format of not only campaigns, but also revolutions.

In addition, we introduce an education index that distinguishes countries by the level of formal education proliferation. It is the variable 'mean years of schooling' (which is discussed below) that we divide into 6 equal parts from the global sample - sextiles. Thus, we obtain:

Sextile 1. Very low level of education (up to 2.02 mean years of schooling).

Sextile 2. Low level of education (from 2.02 to 3.74 mean years of schooling).

Sextile 3. Lower-middle level of education (from 3.74 to 5.25 mean years of schooling).

Sextile 4. Upper-middle level of education (from 5.25 to 7.08 mean years of schooling).

Sextile 5. High level of education (from 7.08 to 9.05 mean years of schooling).

Sextile 6. Very high level of education (from 9.05 mean years of schooling).

By this index, we analyze cross-tabulation with revolutionary protest and revolution formats to determine the joint distribution and relationship between the level of education and frequency of types of revolutionary uprisings. 


\section{Independent variable and Controls}

Our main explanatory variable is the mean years of schooling sourced from the United Nations Development Programme reports database (UNDP: Human Development Reports 2020) and the Barro and Lee (2021) database. The Barro and Lee data go from 1950 up to 2010, therefore their figures were combined with the report by UNDP to cover the period between 2011 and 2019. The method for the calculation of mean years of schooling in the UNDP report is similar to the method used by Barro and Lee (1993 2010), thus making the data transformation possible. The United Nations Development Programme defines this variable as the "average number of years of education received by people ages 25 and older, converted from education attainment levels using official durations of each level" (Jahan 2016, 213). For each age group, the proportion that attained a given level of education is multiplied by the official duration of that level in a given country. The sum of the resulting values yields the mean years of schooling for the population in that specific country.

As one can see, this is very different from the independent variable, the combined education index, proposed by Dahlum (2019), as discussed above. Our variable, mean years of schooling, is easy to assemble, covers a long array of country-years, and allows us to predict the development of revolutionary events rather than simply describing them, as is the case with Dahlum's combined educational index. Of course, the mean years of schooling is likely to have less explanatory power, but this is because it is the ultimate cause, while Dahlum's variable is only proximate. Indeed, the number of students and graduated members in campaigns is a consequence of the general education of the population, which is fully reflected by mean years of schooling.

Thus, we maintain that using the mean years of schooling is a qualitatively new step in the study of the influence of education on the revolutionary event format. It is easy to use, it covers a large time series, and, most importantly, can both explain past revolutions and forecast the future format of forthcoming revolutions, which positively distinguishes it from the index proposed by 
Dahlum. A comparison of descriptive statistics for both variables can be found in Table S1 online (especially note the difference in the number of observations).

Having discussed the main variable, it is worth mentioning some other factors that influence the revolutionary event format and that are to be used as control variables. Note a recent study by Cincotta and Weber (2021), who demonstrate that violent revolutions are significantly more likely in countries with a very high proportion of the youth in the total adult population of this society - the so-called 'youth bulge'. This finding is very congruent with other research on demographic structural factors of revolutions. ${ }^{7}$ This relationship is associated with the fact that young people are easier to engage in violent revolutionary actions because, as "most young people have fewer responsibilities for families and careers, they are relatively easily mobilized for social or political conflicts. Youth have played a prominent role in political violence throughout recorded history, and the existence of a 'youth bulge' (an unusually high proportion of youths 15 to 29 relative to the total adult population) has historically been associated with times of political crisis" (Goldstone 2002, 11-12; see also, e.g., Weber 2019). Thus, the higher the proportion of young people in the population, the higher the likelihood of violent destabilization and the lower stability of the regime (Cincotta and Doces 2012; Farzanegan and Witthuhn 2017; Cincotta and Weber 2021). We operationalize 'youth bulge'through two approaches found in these studies: (1) through the proportion of people in the population between the ages of 15 and 29 in the total adult (15+) population and (2) through the median age of the population. These variables are provided by the United Nations Population Division (UNPD) World Population Prospects database (UNDP 2019), or have been calculated on its basis.

Among other factors proposed as favoring nonviolent rather than violent forms of revolutionary action, one may mention higher GDP per capita and urbanization (e.g., Inglehart and Welzel 2005; Grinin and Korotayev 2016; Korotayev, Bilyuga, and Shishkina 2018). For instance, Inglehart and Welzel (2005) claim that the explosive growth of wealth (using proxy

\footnotetext{
${ }^{7}$ See, e.g., Goldstone 19912002 2017; Korotayev et al. 2011.
} 
through GDP per capita) is also generating a growing need for self-expression including political participation; and the expansion of markets and trade has always been a crucial factor in reducing violence due to the demand for nonviolent communication (Inglehart, Puranen and Welzel 2015). So, higher well-being is associated with higher nonviolent protest activity, because economic development and the natural expansion of the middle class have led to a greater public interest in expanding political and civil liberties (Chenoweth and Ulfelder 2017; Massoud, Doces and Magee 2019). Researchers find robust evidence that GDP per capita is positively associated with nonviolent protests and negatively with violent destabilization (Gleditsch and Rivera 2017; Korotayev, Vaskin and Bilyuga 2017; Korotayev et al. 2018; Dahl et al. 2020) and civil wars (Hegre and Sambanis 2006). This relationship is because high well-being dramatically increases opportunity costs for protesters: people have bigger accumulated investments, and the risk of losing everything overrides all possible benefits. So, if the pre-conflict state equilibrium provides people with a small level of utility, the higher will be the marginal utility of each increase in goods, which pushes people to risk giving up their usual life (Sambanis 2001; Besançon 2005). Moreover, the elites of rich countries can actively use various redistributive policies or co-opt the opposition elite to mitigate general discontent, which is possible due to soft resource constraints (Wimmer, Cederman and Min 2009). Thus, we add the GDP per capita logarithm from the V-Dem dataset (Coppedge et al. 2021) to control our model for the level of well-being.

The level of urbanization is also relevant. For example, mass mobilization is more likely in the most urbanized and complex societies with dispersed social power (Gleditsch and Rivera 2017), where a high concentration of the population and human capital helps disaffected groups find a larger audience (Butcher and Svensson 2016; Chenoweth and Ulfelder 2017; Dahl et al. 2020). It is also important to note that in urbanized areas there is a high likelihood of peaceful protests, whereas, at the periphery radical groups choose another method of disagreement - violent actions (Buhaug and Lujala 2005; Dahl et al. 2020). For our urbanization variable, we take the 
share of the population that lives in urban areas. These data are from the United Nations Population Division (UNPD) World Urbanization Prospects database (UNPD 2021b).

Moreover, a large number of researchers notice that the political sphere also matters. Relatively long ago, Karl Popper said that he calls 'the type of government that can be eliminated without violence "democracy", and the other "tyranny"' (Popper 1949, 90). Modern researchers have similar findings: there is a greater likelihood of peaceful protest mobilization in democracies than in autocratic regimes (Caren, Gaby and Herrold 2017; Chenoweth and Ulfelder 2017; Dahl et al. 2017). This is associated with the facts that: (1) it is easier for dissatisfied citizens to present their demands to the government or to mobilize in a democratic country, where the structure of institutions presupposes the inclusion of broad masses in governance (Nam 2007); (2) a relatively high level of freedoms, or rather, their non-suppression through a repressive apparatus that is not developed in democratic countries, also leads to an increase in the likelihood of a nonviolent protest (Massoud, Doces and Magee 2019). In other words, a higher level of political repression entails increasing the likelihood of violent uprising (Regan and Norton 2005). Thus, democracy does not in itself lead to an increase in discontent but opens the way for its expression through peaceful mass mobilization in polling stations and streets (Dahl et al. 2017). On the other hand, such revolutions as the Ukrainian (Euromaidan) Revolution of 2013-2014, or the Armenian Velvet Revolution of 2018 demonstrate that revolutions may well topple democratically elected presidents, but within an even partly democratic system a revolution is much more likely to take an unarmed form than in a full autocracy. So, type of regime matters, and we introduce index of Electoral Democracy from Varieties of Democracy (V-Dem), that 'is formed by taking the average of, on the one hand, the weighted average of the indices measuring freedom of association thick, clean elections, freedom of expression, elected officials, and suffrage and, on the other, the five-way multiplicative interaction between those indices' (Coppedge et al. 2021, 7), and it scales from 0 to 1 . 
Moreover, it is also necessary to control our model by introducing a variable that can explain ethnic discrimination, because this factor is found to be quite important. The majority of papers in the sphere of the theory of civil war finds that the likelihood of violent uprising onset is positively associated with ethnic discrimination (Gurr 2000; Besançon 2005; Buhaug and Lujala 2005; Regan and Norton 2005; Wimmer, Cederman and Min 2009). It is because the discriminated group is likely to choose a violent tactic rather than a nonviolent one. Firstly, they usually do not have enough opportunities for a successful nonviolent uprising, because dominant ethnic groups own most of the resources and use the state to restrict the access of minorities to various goods as, for example, education (Besançon 2005). Secondly, costs for collective violent action for discriminated ethnic groups are smaller, because: (1) there are stable social ties and trust; (2) opportunity costs are not big, because the well-being of the discriminated group is usually low and they tend not to have big amount of accumulated investments to human capital, (2) consequently, their possible gain from success is large (Sambanis 2001). Thus, we introduce the share of the discriminated population from Ethnic Power Relations (EPR) Dataset that gives the following description: 'group members are subjected to active, intentional, and targeted discrimination by the state, with the intent of excluding them from political power. Such active discrimination can be either formal or informal, but always refers to the domain of public politics (excluding discrimination in the socio-economic sphere)' (Vogt and Rüegger 2021, 6).

In addition, we include several geographical variables that can explain the tactic of protestors, which was noted by several pieces of research (Sambanis 2001; Fearon and Laitin 2003; Wimmer, Cederman and Min 2009). These are the logarithm of the area and population density that are provided by the CNTS Database (Banks, Arthur S., Wilson, Kenneth A. 2021). Of course, it is also necessary to control for the total population that is also positively associated with violent uprisings (Hegre and Sambanis 2006). This variable is presented in thousands by the Department of Economic and Social Affairs of the United Nations Secretariat (UNPD 2021a). 
Finally, we include decade variable to control for time trends that is necessary while one uses panel data.

In sum, a total of 470 maximalist campaigns and 265 revolutions/revolutionary episodes were taken from 14,669 country-year samples with all controls with few missing values from 1950 to 2020 (see Table S1 online).

\section{Multicollinearity problem}

As one can see from Table S2 (online), there is strong multicollinearity between the variables from the 'modernization' group (log per capita GDP, urbanization, and median age/share of youth). All correlations between them are significant and mostly greater than 0.5 . For example, GDP and urbanization are significantly correlated at the 0.839 level, while GDP and median age are significantly correlated at the 0.755 level. Therefore, we are forced not to use all of these variables together to preserve the quality of our analysis. So, to test our hypothesis we will do a separate model for each of these variables.

\section{Results}

In this section, we first present the results of the distribution of campaigns and revolutions across six groups of countries, distinguished by six levels of education, to examine how educational attainment relates to the distribution of violence and nonviolence. We then present logistic models with different controls to test our main hypothesis. Following that, predicted probabilities of campaigns and revolutions on the level of education are shown. Finally, a comparison of effects between mean years of schooling and Dahlum's combined education index is presented. Overall, we find robust evidence that the higher level of education, the lower chance of violence in any form. 
Figure 1 compares the frequency of maximalist campaigns (NAVCO dataset) by six groups of countries. The results obtained from this analysis show that the highest number of cases are in the countries with a very low and low level of education (over 80 campaigns in each group), while the smallest number in the countries with a high and very high level of education (about 40 in each group). In addition, the rate of violent to nonviolent methods is also different between these groups. One can see that if in the first and second groups more than half cases are violent, in the last two groups less than $15 \%$ of events are violent. Countries with high and very high levels of education have almost no violent campaigns. In countries with lower- and upper-middle levels of education, the proportion of violent maximalist campaigns is higher than in the countries with high and very high values of the mean years of schooling, but lower than in the states with low and very low levels of education. Thus, there is a clear relationship: as education increases, the proportion of violent maximalist campaigns decreases.

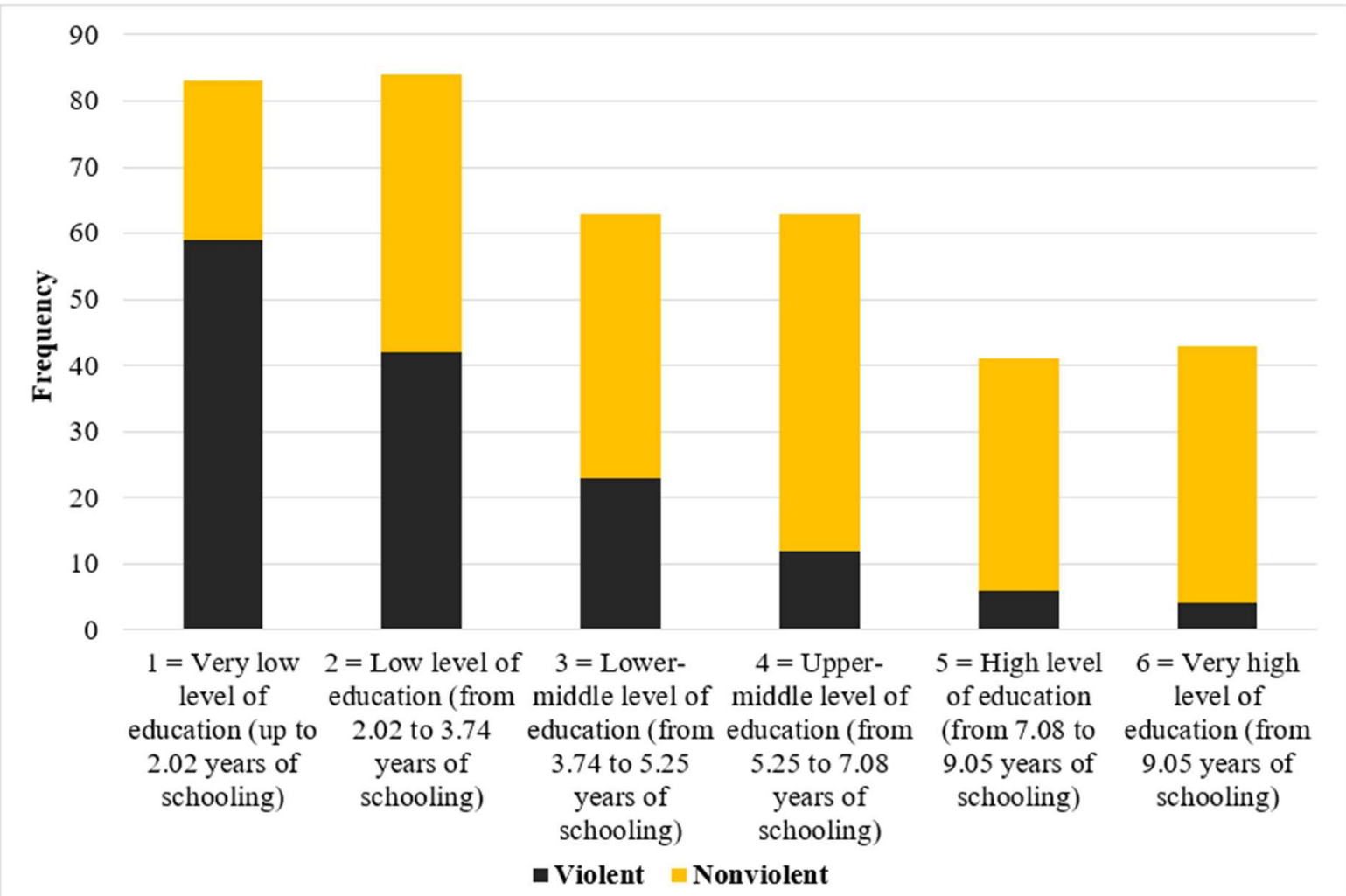

Figure 1. 'Frequency of violent and nonviolent maximalist campaigns in six groups of countries distinguished by the level of formal education enrollment (NAVCO dataset), 1950-2019, $\mathrm{n}=377$ ' 
Similar results are presented in figure 2, where compares the frequency of revolutions by six groups of countries. Obviously, there is the same trend as in the first figure: if the education level increases, violence drops remarkably. If in the first group there is the highest proportion of violent/armed revolutions, in the last group this proportion is the smallest. However, the total number of revolutionary events per group changes much for countries with low and middle levels of education (sextiles from 1 to 4). Following that, there is a huge decrease in the number of revolutionary events from the fourth to the sixth group. Meanwhile, that transition from the high level to a very high level does not affect the number of total cases. However, there is a difference in the amount of violence, because the number of violent/armed revolutionary events drops by more than $50 \%$. Thus, in the case of revolutions, there is also a rather clear relationship: as education increases, the share of violent/armed revolutions decreases.

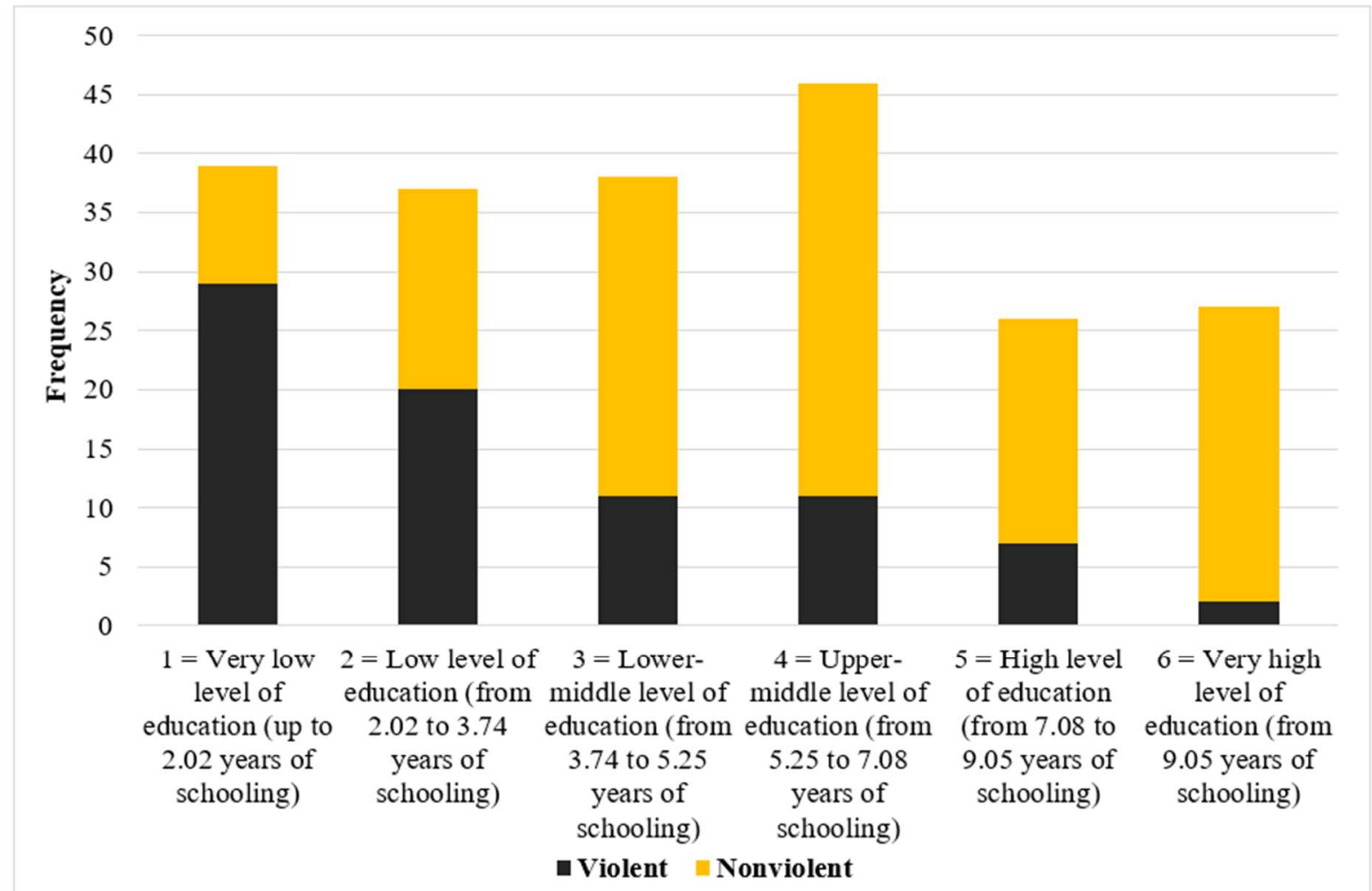

Figure 2. 'Frequency of revolutionary events in six groups of countries distinguished by the level of formal education enrollment (only revolutions), 1950-2021, $\mathrm{n}=213$,

Taken together, the results suggest that there is a clear trend towards a decrease in the amount of violence with the growth of education level. However, while the number of episodes also falls in the case of the campaigns, there is no such thing with revolutions: a significant 
decrease in destabilizing activity begins only with the transition from upper-middle to the high level of education, while the number of cases during transition through the first four education levels stays approximately the same. Interestingly, the most markable decrease in the level of violence is seen with the transition from the very low level to the lower-middle level of education. For both NAVCO's campaigns and revolutionary events, the difference between the first and third levels is more than $50 \%$, while the distinction between high level and very high level is negligible.

\section{Mean years of schooling, revolutionary protests, and revolutions}

The results of the logistic regression between NAVCO's campaigns and mean years of schooling with the set of control variables are presented in Table I. As might be expected, based on our theoretical research, education is indeed positively and significantly associated with the nonviolent type of campaigns in all models with the introduction of all kinds of controls.

Thus, even in M1, which presents a pairwise regression, it is seen that mean years of schooling significantly (at the level $p<0.001$ ) affects the protesters' choice of nonviolent tactic. After controlling for the logarithms of population, area, and population density within M2 and M3, education is still significantly related to nonviolence. Note, none of these controls has a significant effect on the protesters' choice of tactics. In M4 and M5, we introduce the index of electoral democracy and the share of the discriminated population. The most surprising is that democracy itself is not a significant predictor, while the share of the discriminated population is appreciably significant $(p<0.1)$ and associated with a greater likelihood of violence in all subsequent models.

In the further models, the variables from the "modernization" group are added in turn to the already ruminated controls. Thus, the GDP per capita logarithm appears in M6, which is significantly $(p<0.1)$ positively associated with nonviolent tactics, and at the same time reduces 
the significance level of education (from $\mathrm{p}<0.001$ to $\mathrm{p}<0.01$ ) and its effect (from 0.333 to 0.230 ). Note, this model has the smallest prediction error and, therefore, the highest statistical quality (the Akaike's Information Criteria (AIC) is $380.468^{8}$ ) among all the models. In M7 urbanization is introduced. It is a significant $(p<0.1)$ and positive predictor of nonviolence. However, in contrast to the logarithm of GDP per capita, it does not diminish the significance of education and does not affect its effect as much. M8 and M9 add the share of youth and the median age. These controls are not significant and do not affect the relationship between education and nonviolence. Interestingly, these two variables, which operationalize the 'youth bulge', are not significantly different from each other in our analysis, suggesting that it is possible to operationalize it through either of them.

\footnotetext{
${ }^{8}$ In other words, the smaller size of the AIC, the higher quality of the model.
} 
Table I. 'Logistic regression models on violent and nonviolent maximalist campaigns, 1950-2020'

\begin{tabular}{|c|c|c|c|c|c|c|c|c|c|}
\hline & & & & Nonvio & $\operatorname{lent}(=1)$ & s. Violent & $(=0)$ & & \\
\hline & M1 & M2 & M3 & M4 & M5 & $\begin{array}{c}\mathrm{M} 6 \\
\text { (GDP) }\end{array}$ & $\begin{array}{c}\text { M7 } \\
\text { (Urbaniza } \\
\text { tion) }\end{array}$ & $\begin{array}{l}\text { M8 (Share of } \\
\text { youth) }\end{array}$ & $\begin{array}{l}\text { M9 (Median } \\
\text { age) }\end{array}$ \\
\hline $\begin{array}{l}\text { Mean years of } \\
\text { schooling }\end{array}$ & $0.301^{\cdots \cdots}$ & $0.301^{* \cdots *}$ & $0.280^{\ldots \ldots}$ & $0.274^{\cdots \cdots}$ & $0.280^{\ldots \ldots *}$ & $0.150^{* *}$ & $0.196^{* *}$ & $0.236^{* * *}$ & $0.226^{* *}$ \\
\hline & $(0.052)$ & $(0.052)$ & $(0.054)$ & $(0.056)$ & $(0.056)$ & $(0.076)$ & $(0.072)$ & $(0.073)$ & $(0.082)$ \\
\hline $\begin{array}{l}\text { Population } \\
\text { (logged) }\end{array}$ & & 0.041 & 0.053 & 0.042 & 0.069 & 0.064 & 0.145 & 0.039 & 0.043 \\
\hline & & $(0.078)$ & $(0.180)$ & $(0.180)$ & $(0.179)$ & $(0.192)$ & $(0.186)$ & $(0.183)$ & $(0.182)$ \\
\hline Area (logged) & & & 0.0001 & 0.0001 & 0.0001 & 0.0001 & 0.0001 & 0.0001 & 0.0001 \\
\hline & & & $(0.0001)$ & $(0.0001)$ & $(0.0001)$ & $(0.0001)$ & $(0.0001)$ & $(0.0001)$ & $(0.0001)$ \\
\hline $\begin{array}{l}\text { Population } \\
\text { Density }\end{array}$ & & & -0.094 & -0.085 & -0.128 & -0.126 & -0.206 & -0.109 & -0.114 \\
\hline & & & $(0.184)$ & $(0.185)$ & $(0.184)$ & $(0.191)$ & $(0.191)$ & $(0.186)$ & $(0.186)$ \\
\hline Index of & & & & & & & & & \\
\hline Electoral & & & & 0.126 & -0.101 & -0.350 & -0.328 & -0.147 & -0.123 \\
\hline Democracy & & & & $(0.722)$ & $(0.739)$ & $(0.769)$ & $(0.761)$ & $(0.745)$ & $(0.744)$ \\
\hline $\begin{array}{l}\text { Share of the } \\
\text { discriminated }\end{array}$ & & & & & -1.115 & -1.178 & -1.302 & -1.044 & -1.045 \\
\hline & & & & & $(0.807)$ & $(0.818)$ & $(0.830)$ & $(0.808)$ & $(0.809)$ \\
\hline $\begin{array}{l}\text { GDP per capita } \\
\text { (logged) }\end{array}$ & & & & & & $1.123^{* *}$ & & & \\
\hline & & & & & & $(0.500)$ & & & \\
\hline Urbanization & & & & & & & $0.016 \dagger$ & & \\
\hline & & & & & & & $(0.009)$ & & \\
\hline Share of youth & & & & & & & & -0.025 & \\
\hline & & & & & & & & $(0.027)$ & \\
\hline Median age & & & & & & & & & 0.034 \\
\hline & & & & & & & & & $(0.038)$ \\
\hline Constant & $-1.311^{* *}$ & $-1.699^{* *}$ & -0.753 & -0.789 & -0.353 & $-3.740 \dagger$ & -0.290 & 0.850 & -0.870 \\
\hline & $(0.417)$ & $(0.847)$ & (1.398) & (1.409) & $(1.424)$ & (2.046) & (1.432) & (1.947) & (1.546) \\
\hline $\begin{array}{l}\text { Decade fixed } \\
\text { effect }\end{array}$ & Yes & Yes & Yes & Yes & Yes & Yes & Yes & Yes & Yes \\
\hline $\mathrm{N}$ & 377 & 377 & 351 & 348 & 342 & 331 & 342 & 342 & 342 \\
\hline AIC & 416.995 & 418.716 & 392.329 & 393.308 & 389.042 & 377.661 & 387.955 & 390.195 & 390.252 \\
\hline
\end{tabular}

Note: ${ }^{\cdots *} \mathrm{p}<0.001{ }^{\cdots *} \mathrm{p}<0.01 ;{ }^{*} \mathrm{p}<0.05 ;$ †p $<0.1$ 


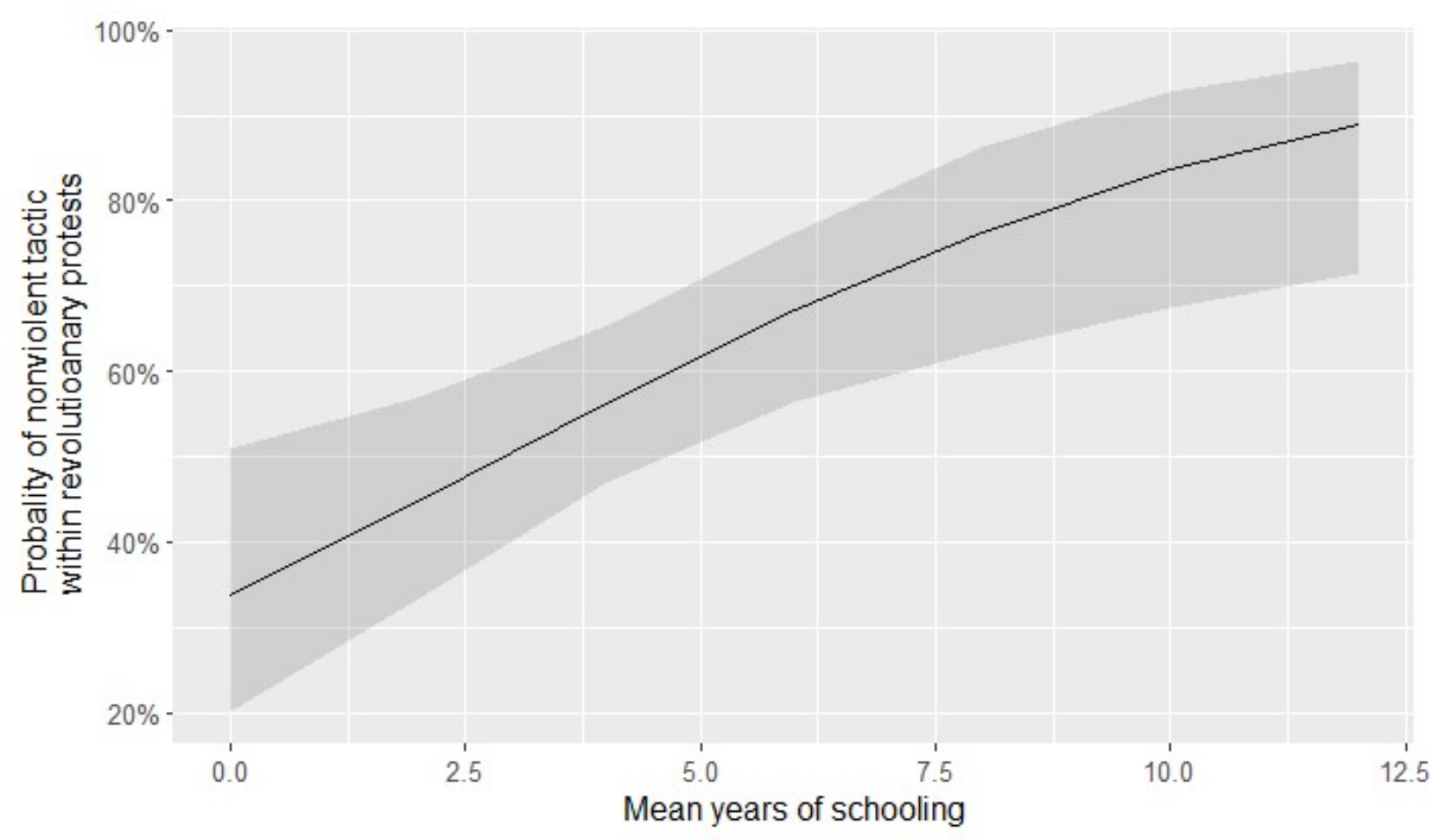

Figure 3. 'The predicted probability of nonviolence (NAVCO dataset)'

To evaluate the effect of education on nonviolent campaigns the plot in figure 3 is introduced. It shows the probability of a peaceful case depending on mean years of schooling with a 95\% confidence interval. Note, this graph is based on M6 from Table II (with logarithm of GDP per capita as a 'modernization control' and the biggest AIC) with mean values of all controls. From the plot, one can see that the highest probability of nonviolence is in countries with the highest level of education. For instance, if the mean years of schooling are 12, then the predicted likelihood of unbloody revolutionary protest is almost at $90 \%$. The lower bound and upper bound of the confidence interval is nearly $70 \%$ and $95 \%$ that also shows, among other things, the accuracy of the model. At the same time, in countries with the lowest level of education probability of nonviolent campaigns is rather low. If the mean years of schooling are close to zero, the likelihood of peaceful maximalist campaign is just about $35 \%$ with the confidence interval from $20 \%$ to $50 \%$. Overall, it can be seen the same tendency as in the first figure: while education increases, the nonviolent/unarmed tactic becomes preferred by the protestors more and more. 
Table II. 'Logistic regression models on nonviolent $v s$. violent revolutionary events, 1950-2020'

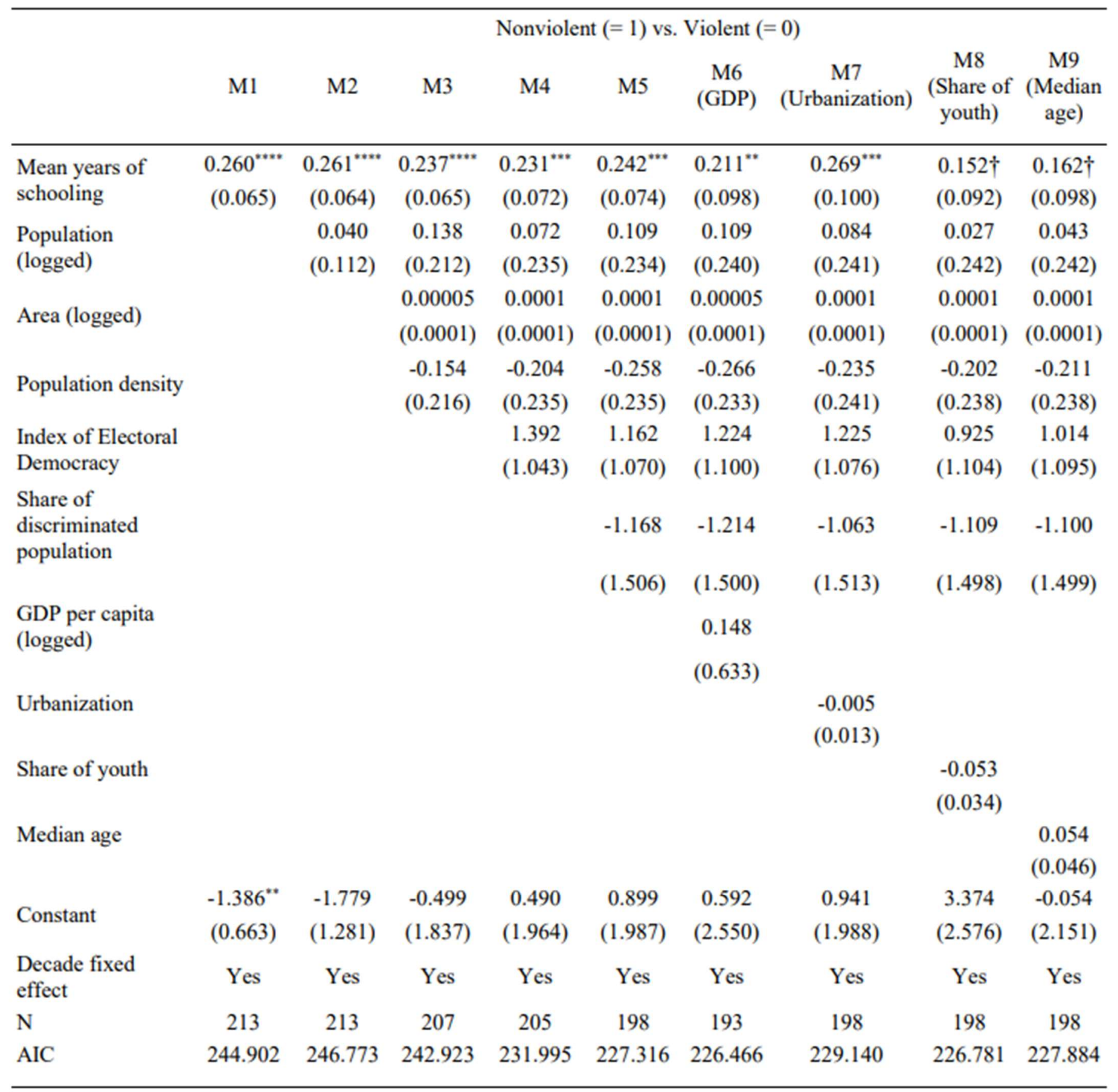

Note: ${ }^{* \cdots *} \mathrm{p}<0.001 ;{ }^{* *} \mathrm{p}<0.01 ; " \mathrm{p}<0.05 ; \dagger \mathrm{p}<0.1$

The second table is similar to the first, but the data from NAVCO is replaced with the dataset of revolutionary events (thus, excluding quasi revolutionary episodes, see Table S3 in the supporting online materials). At the same time, the set of variables in the models and the dependent variable remain unchanged. As expected, mean years of schooling is a consistently significant and 
positive predictor of nonviolent revolutions, as in the case of previous tests with protest campaigns. However, in contrast to previous tests GDP per capita and urbanization are losing their significance in contrast to the previous database. Meanwhile, controls from the 'modernization group' reduce the significance of the independent variable. Overall, this test on revolutions further confirms our hypothesis: the higher the mean years of schooling in a country, the more likely it is to have a nonviolent rather than a violent revolution.

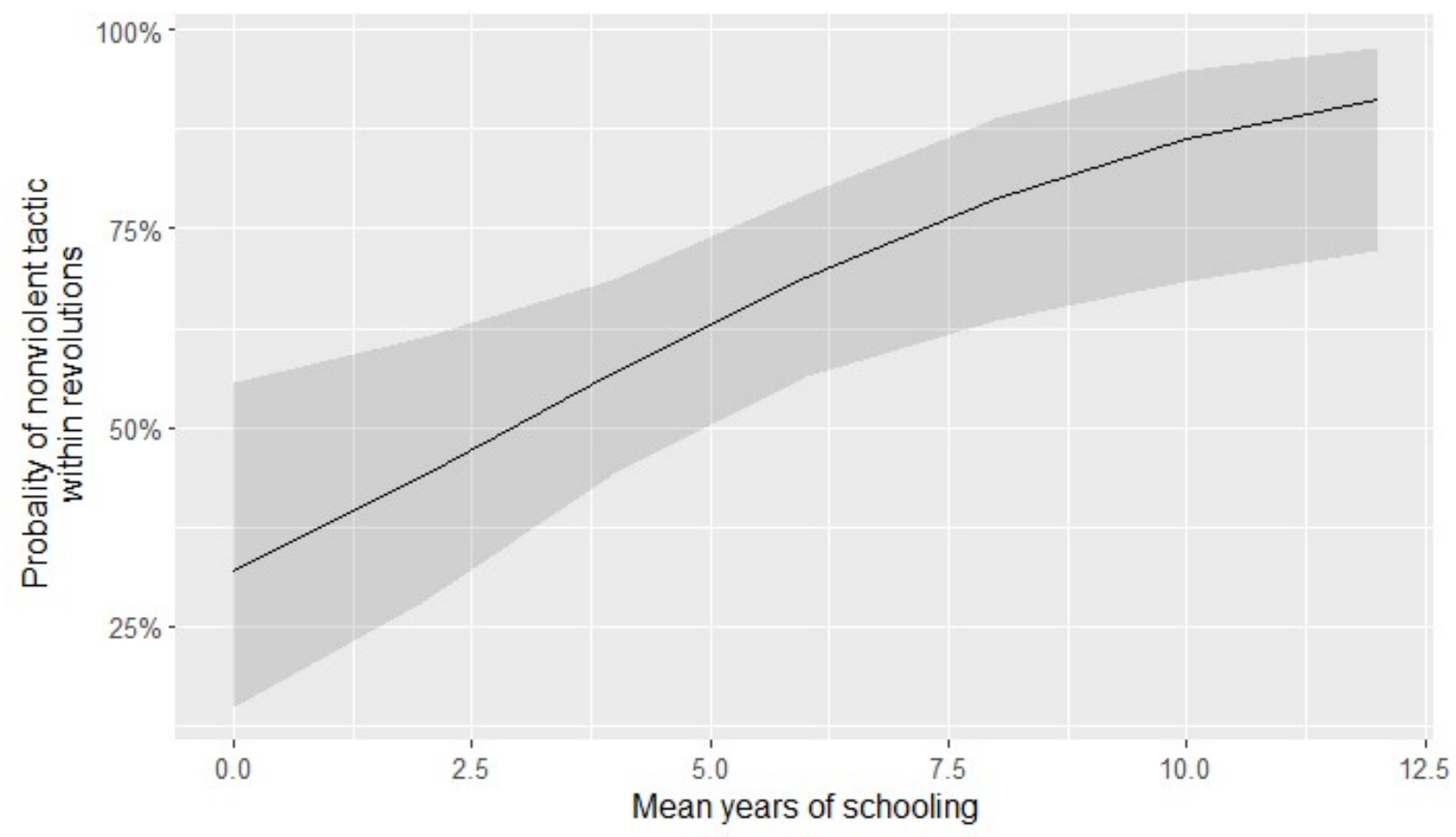

Figure 4. 'The predicted probability of nonviolence (revolutions data)'

Figure 4 shows a similar plot as in figure 3, but it is based on our dataset with revolutions. Broadly put, the conclusions are consistent with those that we have arrived at above with NAVCO. However, the curve slope is higher, suggesting that education is an even stronger inhibitor of the violence of the revolutions than in the case of NAVCO's campaigns. Nevertheless, it should be emphasized that conversely to figure 3 the confidence intervals are larger, which shows less accuracy that can be explained by the reduction of the number of observations in connection with the exclusion of quasi-revolutionary events. 
Taken together, results from NAVCO and the dataset of revolutions support the hypothesis that there is a significant positive relationship between the mean years of schooling and the nonviolent type of revolutionary action. At the same time, in the case of NAVCO, a high level of well-being also encourages protesters to choose peaceful tactics, while a large proportion of the discriminated population predicts that the rebellion will be armed. In contrast, in the case of pure revolutions these factors are insignificant, while the index of electoral democracy is an important and positive predictor of nonviolence. Moreover, the predictive curves confirm the significance and effect of mean years of schooling. However, if the predicted probability of nonviolent NAVCO campaigns is more accurate, the predicted probability of nonviolent revolutions has a greater effect, which is expressed in a steeper slope of the curve.

\section{Comparison of explanatory variables: mean years of schooling versus combined education index}

The results from the third table compare the predictive values of mean years of schooling and Dahlum's combined education index ${ }^{9}$, on the one hand, and NAVCO as the dataset of revolutionary events, on the other. Moreover, to make a qualitative comparison, we restrict both databases to the case where there is data for Dahlum's index.

As one can see from M1 and M2 with pair regressions from the NAVCO data, the significance of mean years of schooling and combined education index are the same, at the $p<0.001$ level, but the quality of the first model is higher. M3 and M4 are similar and confirm previous results in the case of our dataset. Interestingly, Dahlum's variable can also be successfully applied to revolutionary events proper, not just maximalist campaigns. The subsequent M5 and M6 show regressions with mean years of schooling and combined education index together. Variables in both models do not conflict with each other and have equally strong significance.

\footnotetext{
${ }^{9}$ We would remind the readers that Dahlums takes into account the tertiary education level of rebels only, ignoring the proliferation of education among the general population, and refusing to pay any attention to the proliferation of primary and secondary education even among the rebels (let alone the general public).
} 
Moreover, when these explanatory variables are introduced together, the models' quality increases. In M7 with the full set of controls mean years of schooling loses some significance, while the combined education index does not, but in M8 this effect disappears. Interestingly, in the last models none of the controls are significant, unlike previous models (neither for the NAVCO's campaigns nor for the revolutionary events) where the first and second variables were not introduced together.

Table III. 'Logistic regression models on revolution format'

\begin{tabular}{|c|c|c|c|c|c|c|c|c|}
\hline & \multicolumn{8}{|c|}{ Nonviolent $(=1)$ vs. Violent $(=0)$} \\
\hline & $\begin{array}{c}\text { Ml } \\
\text { (NAVCO) }\end{array}$ & $\begin{array}{c}\text { M2 } \\
\text { (NAVCO) }\end{array}$ & $\begin{array}{c}\text { M3 } \\
\text { (Revolutions) }\end{array}$ & $\begin{array}{c}\text { M4 } \\
\text { (Revolutions) }\end{array}$ & $\begin{array}{c}\text { M5 } \\
\text { (NAVCO) }\end{array}$ & $\begin{array}{c}\text { M6 } \\
\text { (Revolutions) }\end{array}$ & $\begin{array}{c}\text { M7 } \\
\text { (NAVCO) }\end{array}$ & $\begin{array}{c}\text { M8 } \\
\text { (Revolutions) }\end{array}$ \\
\hline \multirow{2}{*}{$\begin{array}{l}\text { Mean years of } \\
\text { schooling }\end{array}$} & $0.451^{* * * *}$ & & $0.467^{* * * *}$ & & $0.437^{* * * *}$ & $0.433^{* * * *}$ & $0.350 \dagger$ & $0.359^{* *}$ \\
\hline & $(0.116)$ & & $(0.103)$ & & $(0.127)$ & $(0.114)$ & $(0.186)$ & $(0.160)$ \\
\hline \multirow{2}{*}{$\begin{array}{l}\text { Combined } \\
\text { education index } \\
\text { (Dahlum) }\end{array}$} & & $0.875^{* * *}$ & & $0.965^{* * * *}$ & $0.621^{* * * *}$ & $0.698^{* * * *}$ & $0.876^{* * *}$ & $0.856^{* * *}$ \\
\hline & & $(0.163)$ & & $(0.164)$ & $(0.168)$ & $(0.169)$ & $(0.237)$ & $(0.216)$ \\
\hline \multirow{2}{*}{$\begin{array}{l}\text { Population } \\
\text { (logged) }\end{array}$} & & & & & & & 0.383 & 0.240 \\
\hline & & & & & & & $(0.522)$ & $(0.391)$ \\
\hline \multirow{2}{*}{$\begin{array}{l}\text { Population } \\
\text { Density }\end{array}$} & & & & & & & 0.0001 & 0.00004 \\
\hline & & & & & & & $(0.0003)$ & $(0.0002)$ \\
\hline \multirow{2}{*}{ Area (logged) } & & & & & & & -0.443 & -0.295 \\
\hline & & & & & & & $(0.534)$ & $(0.375)$ \\
\hline \multirow{2}{*}{$\begin{array}{l}\text { Index of } \\
\text { Electoral } \\
\text { Democracy }\end{array}$} & & & & & & & $-3.972 \dagger$ & $-3.419 \dagger$ \\
\hline & & & & & & & $(2.169)$ & $(2.021)$ \\
\hline \multirow{2}{*}{$\begin{array}{l}\text { Share of } \\
\text { Discriminated } \\
\text { population }\end{array}$} & & & & & & & 1.547 & 0.424 \\
\hline & & & & & & & $(1.606)$ & $(1.543)$ \\
\hline \multirow{2}{*}{$\begin{array}{l}\text { GDP per capita } \\
\text { (logged) }\end{array}$} & & & & & & & 1.150 & 1.126 \\
\hline & & & & & & & $(1.071)$ & $(1.011)$ \\
\hline \multirow{2}{*}{ Constant } & $-1.968^{\circ *}$ & $-1.982^{* * *}$ & $-2.373^{* * *}$ & $-2.500^{\circ . *}$ & $-3.065^{* t *}$ & $-3.711^{* * * *}$ & -4.283 & -5.448 \\
\hline & $(0.907)$ & $(0.757)$ & $(0.881)$ & $(0.771)$ & $(1.024)$ & $(1.041)$ & (4.976) & (4.205) \\
\hline $\begin{array}{l}\text { Decade fixed } \\
\text { effect }\end{array}$ & Yes & Yes & Yes & Yes & Yes & Yes & Yes & Yes \\
\hline $\mathrm{N}$ & 105 & 132 & 128 & 155 & 105 & 128 & 97 & 118 \\
\hline AIC & 127.262 & 143.215 & 142.911 & 157.595 & 112.199 & 123.254 & 108.822 & 122.784 \\
\hline
\end{tabular}

Note: ${ }^{\cdots *} \mathrm{p}<0.001{ }^{\cdots} \mathrm{p}<0.01 ; "{ }_{\mathrm{p}}<0.05 ; \dagger \mathrm{p}<0.1$ 


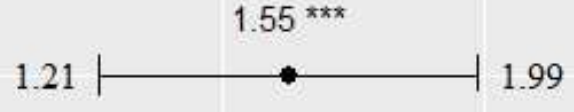

Combined edcation index (Dahlum)

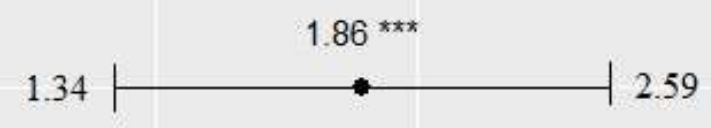

i

2

Corrected ODDS ratio

Figure 5. 'Corrected effects of the mean years of schooling and combined education index on nonviolence'

To evaluate the collaborative effects of mean years of schooling and combined education index on nonviolence, the plot in figure 5 is introduced. It shows the corrected ODDS ratio with a 95\% confident interval of each explanatory variable that is based on M5 from Table III. Overall, the value of each variable falls within the range of the other, indicating approximately the same strength of the effect.

Thus, the Combined Education Index is an important and strong factor, but far from exhaustive. First, when this factor is added together with mean years of schooling into one regression model, both variables are significant, suggesting they are not identical. Second, as can be seen from the analysis of the corrected odds ratio, the strengths of the two variables are roughly comparable. Third, the quality of models is substantially improved when both the mean years of schooling and the Combined Education Index are entered together. Thus, our proposed explanatory variable does not replace Dahlum's one, but it is a significant, powerful, and qualitatively different predictor. 


\section{Discussion and Conclusion}

In this paper, we have attempted to analyze and close a gap in contemporary cross-national research on how education affects the form that a revolution takes - whether a rebellion will be violent/armed or nonviolent/unarmed or, in other words, how education affects protesters' choice of violent or nonviolent tactics. Overall, our hypothesis is fully confirmed: the level of education does contribute to the fact that protesters choose nonviolent protest tactics. Thus, the mean years of schooling is a significant and crucial factor pushing towards nonviolent format of revolutions, which was represented by several logistic models with a set of strong controls.

At the same time, it was found that on average countries with higher mean education have fewer violent events as a proportion of maximalist campaigns and revolutions than countries with lower mean education. More specifically, the most considerable difference there is among countries with very low and lower-middle level of education. In other words, we can assume that education has the highest pacific effect in the early stages of modernization, when the average years of schooling move to approximately four years. Then this effect gradually decreases: overcoming the mark from upper-middle to high level has a markedly less pacifing effect ${ }^{10}$. Moreover, in already developed societies the difference between high and very high level no longer plays a very important role both in the decreasing of violence and the total number of revolutionary events. Also, our analysis suggests, contra Dahlum, that this not only the presence among the campaign participants of students and university graduates that matters - the primary and secondary education matters too. We saw that the greatest effect of the education proliferation on the movement from the violent to nonviolent revolutionary tactics is observed between countries with very low and lower-middle education level, which is achieved first of all through

\footnotetext{
${ }^{10}$ Note the important point, that we discuss average effect of different type of education level, but not real transition from one level to another, because, as Lange showed (2011) the transition itself between education levels in the short term might be accompanied by an increase in aggression.
} 
the proliferation of primary and secondary, but not tertiary education. A natural possible continuation of this work is to analyze this suggestion and test it using different variables that characterize primary, secondary and tertiary education. Note, there are several papers on this topic, but they examine the onset of civil wars, but not the choice of violent $v$. nonviolent tactics by the rebels (see, e.g., Barakat and Urdal 2009; Collier 2004; Thyne 2006).

Also, important that the suggested explanatory variable, mean years of schooling, is a significant, positive, and strong predictor of nonviolence (both for NAVCO's campaigns and pure revolutions) that does not just copy Dahlum's index, but allows a qualitative depth to the research of the problem. So, although our factor is not stronger (also not weaker), it has real predictive power, unlike the combined education index, which can only be a descriptive variable, explaining the violent vs. nonviolent tactics of rebels in retrospect. In other words, Dahlum's Combined Education Index cannot be used to forecast what kind of revolutionary episodes are more likely to be expected in the given country, as this index can only be calculated only after the revolutionary events are over. In contrast to it, the mean years of schooling can be applied for forecasting purposes without any problems. Moreover, these are two qualitatively different and independent factors, because it is not only the tertiary education level of the participants that matters but also the general level of education of the country, which affects not only a much wider circle of the rebels (there are all grounds to expect that rebels with complete secondary education would behave significantly differently in comparison with illiterate rebels), but also the quality of institutions and people on the other side barricades. Thus, mean years of schooling can be seen as more applied and scientifically meaningful, allowing for the further study of violent $v s$. nonviolent revolutionary action.

Turning to other results, it should be emphasized that although education is an important factor of protesters' choice of tactics, it does not the only one. Certainly, there must be other reasons why some revolutions take on a nonviolent character and others a violent one. Our analysis suggests that some economic and political factors might be also vital here. For instance, higher 
well-being (proxied through logarithm of GDP per capita) and urbanization seem to be important factors of "modernization group" making nonviolent/unarmed revolutionary tactics more likely. Though Huntington (1968) claimed that modernization leads to revolutionary conflict as the forces of participation exceed the state's ability to meet the new demands for representation (and Fig. 2 above suggests that the revolutionary events at the intermediate phases of modernization might indeed be somehow more likely than at its initial and final stages), we add that it can also contribute to making revolutionary movements less violent. Although the other variables which characterize modernization were not significant in our analyses, this does not mean that they do not matter. So, a greater focus on these factors could produce interesting findings that were not researched here.

\section{References}

Abd Rabou, Ahmed. 2016. "Democracy as Student Mobilization. How Student Unions Struggle for Change in Egypt." In Education and the Arab Spring: Resistance, Reform, and Democracy, edited by Eid Mohamed, Hannah R. Gerber and Slimane Aboulkacem. Leiden: Brill: 51-67.

Ackerman, Peter and Adrian Karatnycky. 2005. How freedom is won: From civic resistance to durable democracy. New York: Freedom House.

Ackerman, Peter and Christopher Kruegler. 1994. Strategic Nonviolent Conflict: The Dynamics of People Power in the Twentieth Century. Westport: Praeger.

Akaev, Askar, Andrey Korotayev, Leonid Issaev and Julia Zinkina. 2017. "Technological development and protest waves: Arab spring as a trigger of the global phase transition?" Technological Forecasting and Social Change 116: 316-321.

Banks, Arthur S., Wilson, Kenneth A. 2021. Cross-National Time-Series Data Archive. https://www.cntsdata.com/. 
Barakat, Bilal and Henrik Urdal. 2009. "Breaking the waves? Does education mediate the relationship between youth bulges and political violence?" World Bank Policy Research Working Paper No. 5114.

Barro, Robert J and Jong-Wha Lee. 1993. "International comparisons of educational attainment". Journal of Monetary Economics 32 (3): 363-394.

Barro, Robert and Jong-Wha Lee. 2010. "Educational attainment in the world: 1950-2010". NBER Working Paper 15902.

Barro, Robert and Jong-Wha Lee. 2021. Barro-Lee Educational Attainment Dataset. http://www.barrolee.com/.

Bayer, Markus, Felix S Bethke and Daniel Lambach. 2016. "The democratic dividend of nonviolent resistance". Journal of Peace Research 53 (6): 758-771.

Beissinger, Mark R. 2017. A Revolutionary World: The Growth and Urbanization of Global Mass Revolt. Princeton University: Comparative Politics Workshop.

Beissinger, Mark. 2021. Revolutionary City. Princeton, NJ: Princeton University Press.

Besançon, Marie L. 2005. "Relative Resources: Inequality in Ethnic Wars, Revolutions, and Genocides". Journal of Peace Research 42 (4): 393-415.

Brancati, Dawn. 2014. "Pocketbook Protests: Explaining the Emergence of Pro-Democracy Protests Worldwide". Comparative Political Studies 47 (11): 1503-1530.

Buhaug, Halvard and Päivi Lujala. 2005. “Accounting for scale: Measuring geography in quantitative studies of civil war". Political Geography 24 (4): 399-418.

Butcher, Charles and Isak Svensson. 2016. "Manufacturing Dissent". Journal of Conflict Resolution 60 (2): 311-339.

Caren, Neal, Sarah Gaby and Catherine Herrold. 2017. "Economic Breakdown and Collective Action”. Social Problems 64 (1): 133-155. 
Celestino, Mauricio Rivera and Kristian Gleditsch. 2013. "Fresh carnations or all thorn, no rose? Nonviolent campaigns and transitions in autocracies". Journal of Peace Research 50 (3): $385-400$.

Chenoweth, Erica and Christopher Wiley Shay. 2020. NAVCO 1.3 Codebook. (March): 1-16.

Chenoweth, Erica, Maria J Stephan and Maria J Stephan. 2011. Why Civil Resistance Works: The Strategic Logic of Nonviolent Conflict. Columbia University Press.

Chenoweth, Erica and Jay Ulfelder. 2017. "Can Structural Conditions Explain the Onset of Nonviolent Uprisings?” Journal of Conflict Resolution 61 (2): 298-324.

Cincotta, R and John Doces. 2012. "The age-structural maturity thesis". Political Demography 98-116.

Cincotta, Richard and Hannes Weber. 2021. "Youthful Age Structures and the Risks of Revolutionary and Separatist Conflicts”. In Global Political Demography: Comparative Analyses of the Politics of Population Change in All World Regions, edited by Achim Goerres and Pieter Vanhuysse. Cham: Palgrave Macmillan, 57-92.

Clarke, Killian. 2011. "Saying "Enough": Authoritarianism and Egypt's Kefaya Movement”. Mobilization: An International Quarterly 16 (4): 397-416.

Collier, P. 2004. "Greed and grievance in civil war”. Oxford Economic Papers 56 (4): 563-595.

Coppedge, Michael, John Gerring, Carl Henrik Knutsen, Staffan I Lindberg, Jan Teorell, Nazifa Alizada, David Altman, Michael Bernhard, Agnes Cornell and M Steven Fish et al. 2021. V-Dem Dataset v11. 1. Gothenburg: V-Dem Insitute.

Dahl, Marianne, Scott Gates, Kristian Gleditsch and Belen Gonzalez. 2020. "Accounting for numbers: Group characteristics and the choice of violent and nonviolent tactics". Economics of Peace and Security Journal 16 (1): 5-25.

Dahlum, Sirianne. 2019. "Students in the Streets: Education and Nonviolent Protest". Comparative Political Studies 52 (2): 277-309. 
Dahlum, Sirianne and Tore Wig. 2019. "Educating Demonstrators: Education and Mass Protest in Africa”. Journal of Conflict Resolution 63 (1): 3-30.

Dee, Thomas S. 2004. “Are there civic returns to education?” Journal of Public Economics 88 (910): $1697-1720$.

Enikolopov, Ruben, Alexey Makarin and Maria Petrova. 2020. "Social Media and Protest Participation: Evidence From Russia”. Econometrica 88 (4): 1479-1514.

Farzanegan, Mohammad Reza and Stefan Witthuhn. 2017. "Corruption and political stability: Does the youth bulge matter?" European Journal of Political Economy 49: 47-70.

Fearon, James D and David D Laitin. 2003. "Ethnicity, Insurgency, and Civil War". American Political Science Review 97 (1): 75-90.

Gabowitsch, Mischa. 2016. Protest in Putin's Russia. Hoboken: Wiley.

Galston, William A. 2001. "Political Knowledge, Political Engagement, and Civic Education". Annual Review of Political Science 4 (1): 217-234.

Glaeser, Edward L, Giacomo AM Ponzetto and Andrei Shleifer. 2007. "Why does democracy need education?" Journal of Economic Growth 12 (2): 77-99.

Gleditsch, Kristian S and Mauricio Rivera. 2017. "The Diffusion of Nonviolent Campaigns". Journal of Conflict Resolution 61 (5): 1120-1145.

Goldstone, Jack. 1991. Revolution and Rebellion in the Early Modern World. Berkeley, CA: University of California Press.

Goldstone, Jack. 2001. "Toward a fourth generation of revolutionary theory”. Annual Review of Political Science 4 (1): 139-187.

Goldstone, Jack. 2002. "Population and Security: How Demographic Change Can Lead to Violent Conflict”. Journal of International Affairs 56 (1): 3-21.

Goldstone, Jack. 2017. “Demographic Structural Theory: 25 Years On.” Cliodynamics 8 (2): 85112. 
Goldstone, Jack; Leonid Grinin and Andrey Korotayev. 2021a. "Introduction. Changing yet Persistent: Revolutions and Revolutionary Events". In Handbook of Revolutions in the 21st Century, edited by J. Goldstone. Cham: Springer (https://doi.org/10.1007/978-3-03086468-21).

Goldstone, Jack A; Leonid Grinin and Andrey Korotayev. 2021b. The Phenomenon and Theories of Revolution. In Handbook of Revolutions in the 21st Century, edited by J. Goldstone. Cham: Springer (https://doi.org/10.1007/978-3-030-86468-2_1).

Green, Francis, David Ashton and Alan Felstead. 2001. Estimating the determinants of supply of computing, problem-solving, communication, social, and teamworking skills. Oxford Economic Papers 53 (3): 406-433.

Grinin, Leonid and Anton Grinin. 2021. "Revolutionary waves and lines of the 20th century". In Handbook of Revolutions in the 21st Century, edited by J. Goldstone. Cham: Springer (https://doi.org/10.1007/978-3-030-86468-2_12).

Grinin, Leonid, Stanislav Bilyuga, Andrey Korotayev and Sergey Malyzhenkov. 2017. "Share of Students in Total Population and Socio-Political Destabilization (Quantitative Analysis)”. Politeia 87: 35-47.

Grinin, Leonid and Anton Grinin. 2021. "Revolutionary waves and lines of the 20th century". In Handbook of Revolutions in the 21st Century, edited by J. Goldstone. Cham: Springer (https://doi.org/10.1007/978-3-030-86468-2_12).

Grinin, Leonid, and Andrey Korotayev. 2016. Revolution and Democracy: Sociopolitical Systems in the Context of Modernisation. Central European Journal of International and Security Studies 10 (3): 110-131.

Grinin, Leonid, and Andrey Korotayev. 2020. "Metodologicheskie poyasneniya k issledovaniyu revolyutsionnykh sobytii [Methodological Explanaitions to the Studies of Revolutionary Events]". Sistemnyi monitoring globalnykh i regionalnykh riskov 11: 854-861. 
Grinin, Leonid and Andrey Korotayev. 2021. "Revolutions, Counterrevolutions, and Democracy”. In Handbook of Revolutions in the 21st Century, edited by J. Goldstone. Cham: Springer (https://doi.org/10.1007/978-3-030-86468-2_4).

Gurr, Ted Robert. 2000. Peoples versus States: Minorities at Risk in the New Century. Washington: US Institute of Peace Press.

Hall, Robert L, Mark Rodeghier and Bert Useem. 1986. "Effects of Education on Attitude to Protest". American Sociological Review 51 (4): 564-573.

Hegghammer, Thomas. 2013. “The recruiter's dilemma”. Journal of Peace Research 50 (1): 316.

Hegre, Håvard and Nicholas Sambanis. 2006. "Sensitivity Analysis of Empirical Results on Civil War Onset”. Journal of Conflict Resolution 50 (4): 508-535.

Huntington, Samuel P. 1968. Political Order in Changing Societies New Haven: Yale Univ. Press. Inglehart, Ronald F, Bi Puranen and Christian Welzel. 2015. "Declining willingness to fight for one's country". Journal of Peace Research 52 (4): 418-434.

Inglehart, Ronald and Christian Welzel. 2005. Modernization, Cultural Change, and Democracy: The Human Development Sequence. Cambridge: Cambridge University Press.

Jahan, Selim (Ed.). 2016. Human Development Report. http://hdr.undp.org/sites/default/files/2016_human_development_report.pdf.

Jenkins, J Craig and Michael Wallace. 1996. "The generalized action potential of protest movements: The new class, social trends, and political exclusion explanations". Sociological Forum 11 (2): 183-207.

Johnstad, Petter Grahl. 2010. "Nonviolent democratization: A sensitivity analysis of how transition mode and violence impact the durability of democracy". Peace and Change 35 (3): 464-482.

Kadivar, Mohammad Ali and Neil Ketchley. 2018. "Sticks, stones, and Molotov cocktails: Unarmed collective violence and democratization". Socius 4: 1-16. 
Keller, Franziska. 2012. (Why) Do Revolutions Spread? APSA 2012 Annual Meeting Paper.

Kim, Nam Kyu and Alex M Kroeger. 2019. "Conquering and coercing: Nonviolent anti-regime protests and the pathways to democracy". Journal of Peace Research 56 (5): 650-666.

Kleinbaum, David G, K Dietz, M Gail, Mitchel Klein and Mitchell Klein. 2002. Logistic Regression. Springer.

Korosteleva, Elena. 2009. "Was There a Quiet Revolution? Belarus After the 2006 Presidential Election". Journal of Communist Studies and Transition Politics 25 (2-3): 324-346.

Korotayev Andrey, Stanislav Bilyuga, and Alisa Shishkina. 2018. "GDP Per Capita and Protest Activity: A Quantitative Reanalysis”. Cross-Cultural Research 52 (4): 406-440.

Korotayev, Andrey, Patrick Sawyer, Leonid Grinin, Daniil Romanov and Alisa Shishkina. 2020. “Socio-economic Development and Anti-government Protests". Sotsiologicheskiy Zhurnal = Sociological Journal 26 (4): 61-78.

Korotayev Andrey, Ilya Vaskin and Stanislav Bilyuga. 2017. “Olson-Huntington Hypothesis on a Bell-Shaped Relationship Between the Level of Economic Development and Sociopolitical Destabilization: A Quantitative Analysis”. Sociologiceskoe Obozrenie 16 (1): 9-49. Korotayev Andrey; Ilya Vaskin; Stanislav Bilyuga and Ilya Ilyin. 2018. "Economic Development and Sociopolitical Destabilization: A Re-Analysis”. Cliodynamics 9 (1): 59-118.

Korotayev, Andrey and Juliia Zinkina. 2021. Egypt's 2011 revolution: a demographic structural analysis. In Handbook of Revolutions in the 21st Century, edited by J. Goldstone. Cham: Springer (https://doi.org/10.1007/978-3-030-86468-2_25).

Korotayev, Andrey; Julia Zinkina; Svetlana Kobzeva; Justislav Bozhevolnov; Daria Khaltourina; Artemy Malkov and Sergey Malkov. 2011. "A trap at the escape from the trap? Demographic-structural factors of political instability in modern Africa and West Asia". Cliodynamics 2 (2):276-303.

Kostelka, Filip and Jan Rovny. 2019. "It's Not the Left: Ideology and Protest Participation in Old and New Democracies". Comparative Political Studies 52 (11): 1677-1712. 
Lange, Matthew. 2011. Educations in Ethnic Violence: Identity, Educational Bubbles, and Resource Mobilization. Cambridge: Cambridge University Press.

Lawson, George. 2019. Anatomies of Revolution. Cambridge: Cambridge University Press.

Lipset, Seymour Martin. 1960. Political man: The social bases of politics. Garden City: Doubleday.

Lipset, Seymour Martin. 1968. "Students and Politics in Comparative Perspective". Daedalus 97 (1): $1-20$.

Machado, Fabiana, Carlos Scartascini and Mariano Tommasi. 2011. "Political Institutions and Street Protests in Latin America”. Journal of Conflict Resolution 55 (3): 340-365.

Massoud, Tansa George, John A Doces and Christopher Magee. 2019. "Protests and the Arab Spring: An Empirical Investigation”. Polity 51 (3): 429-465.

Moshes, Arkady, and Ryhor Nizhnikau. 2021. "The Belarusian Revolution: Sources, Interim Outcomes, and Lessons To Be Learned”. Demokratizatsiya 29 (2): 159-181.

Nam, Taehyun. 2007. "Rough days in democracies: Comparing protests in democracies". European Journal of Political Research 46 (1): 97-120.

Østby, Gudrun, Henrik Urdal and Kendra Dupuy. 2019. "Does Education Lead to Pacification? A Systematic Review of Statistical Studies on Education and Political Violence". Review of Educational Research 89 (1): 46-92.

Pinker, Steven. 2011. The Better Angels of Our Nature: The Decline of Violence in History and Its Causes. London: Penguin.

Popper, Karl R. 1949. "Prediction and prophecy and their significance for social theory". Proceedings of the Tenth International Congress of Philosophy 1: 82-91.

Rasler, Karen, William R Thompson and Hichem Bou Nassif. 2021. "The Extent of Military Involvement in Non-Violent, Civilian Revolts and Their Aftermath". In Handbook of Revolutions in the 21st Century, edited by J. Goldstone. Cham: Springer (https://doi.org/10.1007/978-3-030-86468-2_29). 
Regan, Patrick M and Daniel Norton. 2005. "Greed, Grievance, and Mobilization in Civil Wars". Journal of Conflict Resolution 49 (3): 319-336.

Sambanis, Nicholas. 2001. "Do Ethnic and Nonethnic Civil Wars Have the Same Causes?" Journal of Conflict Resolution 45 (3): 259-282.

Sawyer, Patrick and Andrey Korotayev. 2021. "Formal Education and Contentious Politics: The Case of Violent and Non-Violent Protest". Political Studies Review: https://doi.org/10.1177/1478929921998210.

Shayo, Moses. 2007. Education, Militarism and Civil Wars. Jerusalem: Maurice Falk Institute.

Stephan, Maria J and Erica Chenoweth. 2008. "Why Civil Resistance Works: The Strategic Logic of Nonviolent Conflict”. International Security 33 (1): 7-44.

Stradiotto, Gary A and Sujian Guo. 2010. "Transitional modes of democratization and democratic outcomes". International Journal on World Peace 5-40.

Thyne, Clayton L. 2006. “ABC's, 123's, and the Golden Rule: The Pacifying Effect of Education on Civil War, 1980-1999”. International Studies Quarterly 50 (4): 733-754.

UNDP: Human Development Reports. 2020. UNDP. http://hdr.undp.org/en/indicators/103006.

UNPD [= United Nations, Department of Economic and Social Affairs, Population Division]. 2021a. World Population Prospects, Online Edition. https://population.un.org/wpp/Download/Standard/Population/.

$\mathrm{UNPD}=[$ United Nations, Department of Economic and Social Affairs, Population Division $]$. 2021b. World Urbanization Prospects, Online Edition. https://population.un.org/wup/Download/.

United Nations, Department of Economic and Social Affairs, Population Division. 2019. World Population Prospects 2019, Online Edition. Rev. 1. https://population.un.org/wpp/Download/Standard/Population/.

Vogt, Manuel and Seraina Rüegger. 2021. The Ethnic Power Relations (EPR) Core Dataset, Codebook Version 2021. 
Weber, Hannes. 2019. “Age structure and political violence: a re-assessment of the 'youth bulge' hypothesis". International Interactions 45 (1): 80-112.

Wimmer, Andreas, Lars-Erik Cederman and Brian Min. 2009. "Ethnic Politics and Armed Conflict: A Configurational Analysis of a New Global Data Set”. American Sociological Review 74 (2): 316-337. 